\title{
Nutritive Value, Polyphenol Constituents and Prevention of Pathogenic Microorganism by Different Resin Extract of Commiphora myrrh
}

\author{
Rasha Khalid Abbas ${ }^{1,2 *}$ (D) Amina A.M. Al-Mushhin ${ }^{3}$, Fatima S. Elsharbasy ${ }^{4,5}$ and \\ Kother Osman Ashiry ${ }^{6}$
}

${ }^{1}$ Department of Chemistry, Faculty of Science and Arts in Mukhwa, University of Albaha, 65931 Saudi Arabia. ${ }^{2}$ Department of Biochemistry, Faculty of Applied and Industrial Science University of Bahri, Sudan.

${ }^{3}$ Department of Biology, Science and Humanity College in Al-kharj, Prince Sattam bin Abdul-Aziz University AlKhaarj 11942, Saudi Arabia.

${ }^{4}$ Department of Chemistry, Faculty of Science and Humanity studies, Sattam bin Abdul Aziz University, Alkharj City 11942, Saudi Arabia.

${ }^{5}$ Department of Chemistry of Natural and Microbial Products, National Research Center, Dokki 12622, Egypt.

${ }^{6}$ Department of Chemistry, Faculty of Science and Arts in Mukhwa, University of Albaha, 65931 Saudi Arabia.

\begin{abstract}
The resin extract of Commiphora myrrh is Widely used in the folk medicine. The studying myrrh resin extract include moisture. minerals such as ( $\mathrm{Ca}, \mathrm{Fe}, \mathrm{Mg}, \mathrm{Na}, \mathrm{Cu}$ and $\mathrm{Zn}$ ), protein, total fat and crude fiber. In this study used Muffle furnace, Kjeldahl methods Soxlet and atomic absorption. HPLC using to evaluating Polyphenol constituents of myrrh different resin extract (ethanol, ethyl acetate, petroleum ether and chloroform) as Conc. ( $\mu \mathrm{g} / \mathrm{g}$ ) and in all extract (ethanol, ethyl acetate and petroleum ether and chloroform) it contained Chlorogenic acid, gallic acid Catechin, Coffeic acid, caffeine, Syringic acid, Coumaric acid, Ferulic acid, Naringenin, 4'.7-Dihydroxyisoflavone, Cinnamic, Propyl Gallate Vanillin, Querectin and Acid Ellagic acid in different concentration percentage and area The effect of Commiphora myrrh (ethanol, ethyl acetate, petroleum ether and chloroform) resin extract against four different pathogenic bacteria Salmonella typhimurium, Pseudomona aeruginosa, Escherichia coli, and Bacillus cereus, were examine by Mueller Hinton Agar and measuring inhibition zone (diameter $\mathrm{mm}$ ), show that there were significant different among bacteria and different method of extract. All different Commiphora myrrh seed extract (aqueous, ethyl acetate and petroleum ether) have high activity against Candida albicans fungus. The study was conducted to identified the Commiphora myrrh nutritive value, polyphenol Compound and the activity against bacteria and fungi.
\end{abstract}

Keywords: Commiphora myrrh, nutritive value, poly phenol constituent, antimicrobial, antifungal

*Correspondence: rashakhalid09@gmail.com

(Received: February 4, 2020; accepted: July 4, 2020)

Citation: Abbas RK, Al-Mushhin AAM, Elsharbasy FS, Ashiry KO. Nutritive Value, Polyphenol Constituents and Prevention of Pathogenic Microorganism by Different Resin Extract of Commiphora myrrh. J Pure Appl Microbiol. 2020;14(3):1871-1878. doi: 10.22207/JPAM.14.3.26

(C) The Author(s) 2020. Open Access. This article is distributed under the terms of the Creative Commons Attribution 4.0 International License which permits unrestricted use, sharing, distribution, and reproduction in any medium, provided you give appropriate credit to the original author(s) and the source, provide a link to the Creative Commons license, and indicate if changes were made. 


\section{INTRODUCTION}

Commiphora myrrh are small tree family Burseraceae. Myrrh native to the northeastern Africa, Somalia, Madagascar, India. Ethiopia, Iran, and Thailand ${ }^{1-7}$. Myrrh traditionally widely used in folk medicine, which has no toxicity ${ }^{8,9}$, myrrh resin was used in many medicinal purposes ${ }^{10}$, Myrrh used for inflammations of the mouth, throat is highly effective antiseptic astringent, has widely used in digestive tract diseases ${ }^{11-14}$. Its antibacterial ${ }^{14,15}$. Myrrh have antifungal activity $^{16}$ anti-parasitic, detoxifying and reduced inflammation ${ }^{17,18}$. It can be used in remedy for chronic sinusitis. Myrrh is used in skin problems rashes, acne, and inflammatory also used in healing gastric ulcer or skin injury as powder, or essential oil ${ }^{19,20}$. It play an important role in cosmetics and perfumery.

\section{MATERIAL}

Commiphora myrrh purchase in the super market and identified in the Department of Biology, Science and Humanity College in Al-kharj, Prince Sattam bin Abdul-Aziz.

\section{Microorganism}

Microorganisms used in this work were obtained from laboratories of Microbiology "National Research Centre, Khartoum Sudan. The identification of bacterial by conventional biochemical methods ${ }^{21}$ according to the standard microbiology techniques. These microbes were, Pseudomonas aeruginosa, Escherichia coli, Bacillus cereus and Salmonella typhimurium.

\section{METHODS}

\section{Moisture content}

content ${ }^{22}$.

Oven used for determination of moisture

Ash content ash $\%^{23}$.

Muffle furnace used for determination of

\section{Determination of total fat}

of fat ${ }^{23}$

A Sox let extractor used for determination

\section{Determination of crude fiber}

Determination according to the method described by Official methods of analysis of the association of analytical Chemists ${ }^{23}$.

Determination of protein as total nitrogen

The Kjeldahl method used for determination of protein ${ }^{23}$.

\section{Determination of minerals}

Atomic absorption spectrophotometry

used for determination of the minerals ${ }^{23}$.

Determination of total carbohydrate

According to the method described by Official methods of analysis of the association of analytical $\mathrm{Chemists}^{23}$.

\section{Preparation of plants extracts}

$100 \mathrm{~g}$, of resin plant were weighed, and subjected to different extraction solvents separately extracted with ethanol $80 \%$ at $60^{\circ} \mathrm{C}$ for $2 \mathrm{~h}$ in a Sox let apparatus ethyl acetate $80 \%$ at $50^{\circ} \mathrm{C}-60^{\circ} \mathrm{C}$ for $2 \mathrm{~h}$, petroleum ether $80 \%$ at $60^{\circ} \mathrm{C}$ for $2 \mathrm{~h}$ Chloroform $80 \%$ at $50^{\circ} \mathrm{C}-60^{\circ} \mathrm{C}$ for $2 \mathrm{~h}$. The all solvents extract were evaporated by a Buchi Rotary evaporator under reduced pressure, also the resin plant was extracted by distilled water over night at room temperature $\left(25-30^{\circ} \mathrm{C}\right)$ filtered and dried ${ }^{24}$.

\section{HPLC conditions}

The Agilent series 1260, Kromasil C18 column ( $4.6 \mathrm{~mm} \times 250 \mathrm{~mm}$ i.d., $5 \mu \mathrm{m}$ ) were used for the separation in HPLC analysis. The mobile phase used consisted of water (A) and $0.1 \%$ trifloro-acetic acid in acetonitrile (B) at a flow rate $1 \mathrm{ml} / \mathrm{min}$. The mobile phase was programmed consecutively in a linear gradient as follows: $0 \mathrm{~min}$ (82\% A); 0-5 min (80\% A); 5-8 $\min (60 \% A) ; 8-12$ $\min (60 \% A) ; 12-15 \min (85 \% A)$ and $15-16 \min$ $(82 \% \mathrm{~A})$. The column temperature was maintained at $35^{\circ} \mathrm{C}$. The multi-wavelength detector was monitored at $280 \mathrm{~nm}$. The injection volume was $10 \mu \mathrm{l}$ for each of the sample solutions.

\section{Mueller Hinton Agar}

MHA (Mueller Hinton Agar) (Becton Dicknson M. D USA), media was prepared according to the manufacturer's instruction. Sterile Mueller Hinton agar plates were inoculated with the test culture by surface spreading using sterile wire loops and each bacterium evenly spread on the entire surface of the plate to obtain uniformity of the inoculum. Concentrations of 12.5, 25, 50 and $100 \mathrm{mg} / \mathrm{ml}$ prepared from the seed different extract (aqueous, ethyl acetate and petroleum ether) agar were used for antibacterial analysis. Petri dishes prepared by agar and allow to solidify. Each plate was then seeded with a test bacterium. Four holes were made in each of the plate with a sterile $2.0 \mathrm{~mm}$ diameter cork borers. Each of the 
four holes was filled with a given concentration of the extract mixed with plane sterile agar. The plates were then incubated at $37^{\circ} \mathrm{C}$ for 24 hours. The diameters of zones of inhibition were measured using a meter rule and the mean value for each organism was recorded ${ }^{25}$.

\section{Preparation of fungal organism}

The fungal is culture as fallow at temperature $25^{\circ} \mathrm{C}$ for 4 days put in Peptone water, sterile normal saline used for the harvested growth mat of fungal, washed and suspended stored in refrigerator till used ${ }^{26}$.

\section{Statistical analysis} Range Test127.

It was done according to Duncan, Multiple

\section{RESULTS AND DISCUSSION}

Table 1. show the approximate nutritive constituent of Commiphora myrrh resin contain Moisture \% (0.10) , ash\% (15.40), fiber\% (0.0), protein\% (9.97), carbohydrates\% (56.01), fat\% (17.96). Table 2. show the minerals content of the myrrh (ppm) such as Ca (20.80), Fe (139.540), Mg (359.203), $\mathrm{Na}$ (39.1), $\mathrm{Cu}(0.654)$ and $\mathrm{Zn}$ (0.6561), $(26,28)$. Fig. 1 and Table 3 . show the 17 Polyphenol constituents of Commiphora myrrh ethanol resin extract according to concentration and area, Querectin gave the highest concentration (54.31Conc. ( $\mu \mathrm{g} / \mathrm{ml}=\mu \mathrm{g} / 20 \mathrm{mg}$ ) while Pyro catechol and Ellagic acid gave $(0.00 \%)$ Table 4. and figure 2 show the Commiphora myrrh resin

Table 1. Nutritional value per $100 \mathrm{~g}$ (3.5 oz) of Commiphora myrrh. resin extract

\begin{tabular}{ll}
\hline Moisture & 0.10 \\
Ash & 15.40 \\
Fiber & 0.0 \\
Protein & 9.97 \\
Carbohydrate & 56.01 \\
Fat & 17.96 \\
\hline
\end{tabular}

Table 2. Mineral constituents (ppm) of Commiphora myrrh. Resin extract

\begin{tabular}{ll}
\hline $\mathrm{Ca}$ & 20.80 \\
$\mathrm{Fe}$ & 139.540 \\
$\mathrm{Mg}$ & 359.203 \\
$\mathrm{Na}$ & 39.1 \\
$\mathrm{Cu}$ & 0.654 \\
$\mathrm{Zn}$ & 0.6561
\end{tabular}

extracted by ethyl acetate contained 13 polyphenol the highest concentration is Querectin (211.14 Conc. $(\mu \mathrm{g} / \mathrm{ml}=\mu \mathrm{g} / 15 \mathrm{mg}$ ) while the lower one is Cinnamic acid (3.41 Conc. ( $\mu \mathrm{g} / \mathrm{ml}=\mu \mathrm{g} / 15 \mathrm{mg}$ ). Table 5. and figure3 show the Commiphora myrrh

Table 3. Commiphora myrrh resin ethanol extract (20 mg / ml)

\begin{tabular}{llll}
\hline & Area & $\begin{array}{l}\text { Conc. } \\
(\mu \mathrm{g} / \mathrm{ml}= \\
\mu \mathrm{g} / 20 \mathrm{mg})\end{array}$ & $\begin{array}{l}\text { Conc. } \\
(\mu \mathrm{g} / \mathrm{g})\end{array}$ \\
\hline Gallic acid & 67.35 & 4.34 & 216.84 \\
Chlorogenic acid & 28.36 & 1.75 & 87.56 \\
Catechin & 61.17 & 10.15 & 507.51 \\
Caffeine & 83.83 & 2.43 & 121.71 \\
Coffeic acid & 99.76 & 3.29 & 164.33 \\
Syringic acid & 101.70 & 3.82 & 190.96 \\
Rutin & 171.24 & 25.79 & 1289.50 \\
Pyro catechol & 0.00 & 0.00 & 0.00 \\
Ellagic acid & 0.00 & 0.00 & 0.00 \\
Coumaric acid & 41.05 & 0.92 & 45.79 \\
Vanillin & 46.57 & 1.63 & 81.74 \\
Ferulic acid & 176.56 & 3.76 & 188.11 \\
Naringenin & 207.26 & 8.42 & 420.76 \\
Propyl Gallate & 824.35 & 20.03 & 1001.61 \\
4.7Dihydroxyiso & 600.45 & 15.10 & 754.82 \\
Flavone & & & \\
Querectin & 674.27 & 54.31 & 2715.62 \\
Cinnamic acid & 461.17 & 3.76 & 187.84 \\
\hline
\end{tabular}

Table 4. Commiphora myrrh resin ethyl acetate extract (Conc. $15 \mathrm{mg} / \mathrm{ml}$ )

\begin{tabular}{|c|c|c|c|}
\hline \multicolumn{4}{|c|}{ Commiphora myrrh Ethyl acetate (Conc. 15 mg/ml) } \\
\hline & Area & $\begin{array}{l}\text { Conc. } \\
(\mu \mathrm{g} / \mathrm{ml}= \\
\mu \mathrm{g} / 15 \mathrm{mg})\end{array}$ & $\begin{array}{l}\text { Conc. } \\
(\mu \mathrm{g} / \mathrm{g})\end{array}$ \\
\hline Gallic acid & 273.98 & 20.37 & 1357.68 \\
\hline $\begin{array}{l}\text { Chlorogenic } \\
\text { acid }\end{array}$ & 198.63 & 12.82 & 854.34 \\
\hline Catechin & 234.47 & 37.76 & 2517.42 \\
\hline Coffeic acid & 193.22 & 6.67 & 444.43 \\
\hline Syringic acid & 311.13 & 11.37 & 758.04 \\
\hline Rutin & 1037.40 & 134.54 & 8969.27 \\
\hline Ellagic acid & 1066.67 & 67.05 & 4470.27 \\
\hline Coumaric acid & 278.07 & 11.67 & 778.15 \\
\hline Vanillin & 304.74 & 7.15 & 476.75 \\
\hline Ferulic acid & 395.72 & 13.04 & 869.28 \\
\hline Naringenin & 1797.77 & 100.81 & 6720.83 \\
\hline Querectin & 530.56 & 211.14 & 14076.01 \\
\hline Cinnamic acid & 375.73 & 3.41 & 227.29 \\
\hline
\end{tabular}


resin extracted by petroleum ether contained 13 Polyphenol constituents the highest one is Querectin (78.44 Conc. ( $\mu \mathrm{g} / \mathrm{ml}=\mu \mathrm{g} / 15 \mathrm{mg}$ ) while the lower one is Gallic acid and Coffeic acid $(0.00$ Conc. ( $\mu \mathrm{g} / \mathrm{ml}=\mu \mathrm{g} / 15 \mathrm{mg}$ ) Table 6 . and figure 4 show the Commiphora myrrh resin extracted by Chloroform contained 13 Polyphenol constituents the higher one is Querectin (182.45 Conc. ( $\mu \mathrm{g} /$ $\mathrm{ml}=\mu \mathrm{g} / 15 \mathrm{mg}$ ) while the lower one is Gallic acid (0.00 Conc. ( $\mu \mathrm{g} / \mathrm{ml}=\mu \mathrm{g} / 15 \mathrm{mg}$ ) In all extract show that the Querectin have high concentration, many studies reported the presence of phenolic compounds prevent body against oxidation, cancer and inflammation ${ }^{28-30}$. The antibacterial activity of the Commiphora myrrh by different method

Table 5. Commiphora myrrh resin petroleum ether extract (Conc. $15 \mathrm{mg} / \mathrm{ml}$ )

\begin{tabular}{llll}
\hline \multicolumn{4}{c}{ Commiphora myrrh Petroleum ether (Conc. $15 \mathrm{mg} / \mathrm{ml})$} \\
\hline & Area & $\begin{array}{l}\text { Conc. } \\
(\mu \mathrm{g} / \mathrm{ml}=\end{array}$ & $\begin{array}{l}\text { Conc. } \\
(\mu \mathrm{g} / \mathrm{g})\end{array}$ \\
& & $\mu \mathrm{g} / 15 \mathrm{mg})$ & \\
\hline Gallic acid & 0.00 & 0.00 & 0.00 \\
Chlorogenic acid & 6.89 & 0.44 & 29.66 \\
Catechin & 9.35 & 1.51 & 100.40 \\
Coffeic acid & 0.00 & 0.00 & 0.00 \\
Syringic acid & 32.22 & 1.18 & 78.50 \\
Rutin & 38.84 & 5.04 & 335.78 \\
Ellagic acid & 58.12 & 3.65 & 243.57 \\
Coumaric acid & 22.16 & 0.93 & 62.02 \\
Vanillin & 82.42 & 1.93 & 128.94 \\
Ferulic acid & 86.74 & 2.86 & 190.55 \\
Naringenin & 90.78 & 5.09 & 339.38 \\
Querectin & 197.10 & 78.44 & 5229.17 \\
Cinnamic acid & 41.65 & 0.38 & 25.20 \\
\hline
\end{tabular}

(ethanol, ethyl acetate, petroleum ether) seed extract against four different pathogenic organisms Escherichia coli, Pseudomona aeruginosa, Salmonella typhimurium and Bacillus cereus and one fungus Candida albicans (the lowest concentration of the Commiphora myrrh seed extract is $(12.5 \mathrm{mg} / \mathrm{ml})$ and the highest one is $(100 \mathrm{mg} / \mathrm{ml})$ there were differences effect among bacteria, Table 7 shows the inhibition zone (in $\mathrm{mm}$ ) for different concentrations of Commiphora myrrh ethanol resin extract, the highest inhibition zone was detected against Bacillus cereus (13.75) and have the lowest one is Pseudomona aeruginosa (12.25). Table 8 show that the Commiphora myrrh resin extracted by ethyl acetate, the high inhibited

Table 6. Commiphora myrrh resin chloroform extract (Conc. $15 \mathrm{mg} / \mathrm{ml}$ )

\begin{tabular}{llll}
\multicolumn{3}{l}{ Commiphora myrrh Chloroform (Conc. $15 \mathrm{mg} / \mathrm{ml})$} \\
\hline & Area & $\begin{array}{l}\text { Conc. } \\
(\mu \mathrm{g} / \mathrm{ml}=\end{array}$ & $\begin{array}{l}\text { Conc. } \\
(\mu \mathrm{g} / \mathrm{g})\end{array}$ \\
& & $\mu \mathrm{g} / 15 \mathrm{mg})$ & \\
\hline Gallic acid & 0.00 & 0.00 & 0.00 \\
Chlorogenic acid & 14.62 & 0.94 & 62.87 \\
Catechin & 16.81 & 2.71 & 180.51 \\
Coffeic acid & 19.79 & 0.68 & 45.51 \\
Syringic acid & 34.57 & 1.26 & 84.24 \\
Rutin & 49.20 & 6.38 & 425.35 \\
Ellagic acid & 237.37 & 14.92 & 994.79 \\
Coumaric acid & 56.46 & 2.37 & 157.99 \\
Vanillin & 258.43 & 6.06 & 404.29 \\
Ferulic acid & 210.19 & 6.93 & 461.71 \\
Naringenin & 55.69 & 3.12 & 208.20 \\
Querectin & 458.47 & 182.45 & 12163.41 \\
Cinnamic acid & 114.01 & 1.03 & 68.97 \\
\hline
\end{tabular}

Table 7. Inhibition zone (in $\mathrm{mm}$ ) for different concentrations of Commiphora myrrh ethanol resin extract

\begin{tabular}{|c|c|c|c|c|c|}
\hline \multirow[t]{2}{*}{ Microorganism } & \multicolumn{4}{|c|}{$\begin{array}{l}\text { Concentration of the of } \\
\text { Commiphora myrrh ethanol } \\
\text { resin extract }(\mu \mathrm{g} / \mathrm{disc})\end{array}$} & \multirow[t]{2}{*}{$\begin{array}{l}\text { Mean } \\
\text { Microorganism }\end{array}$} \\
\hline & 12.5 & 25 & 50 & 100 & \\
\hline Salmonella typhimurium & 12 & 13 & 14 & 15 & 13.5 \\
\hline Pseudomonas aeruginosa & 10 & 12 & 12 & 15 & 12.25 \\
\hline Escherichia coli & 12 & 13 & 14 & 15 & 13.5 \\
\hline Bacillus cereus & 10 & 14 & 15 & 16 & 13.75 \\
\hline Candida albicans & 10 & 13 & 14 & 15 & 13 \\
\hline $\begin{array}{l}\text { Mean Commiphora myrrh } \\
\text { ethanol resin extract }\end{array}$ & 10.8 & 13 & 13.8 & 15.2 & \\
\hline
\end{tabular}


Table 8. Inhibition zone (in $\mathrm{mm}$ ) for different concentrations of Commiphora myrrh ethyl acetate resin extract

\begin{tabular}{llllll}
\hline Microorganism & \multicolumn{4}{c}{$\begin{array}{c}\text { Concentration of the of } \\
\text { Commiphora myrrh ethyl } \\
\text { acetate resin extract }(\mu \mathrm{g} / \mathrm{disc})\end{array}$} & $\begin{array}{l}\text { Mean } \\
\text { Microorganism }\end{array}$ \\
\hline Salmonella typhimurium & 12.5 & 25 & 50 & 100 & \\
Pseudomonas aeruginosa & 12 & 13 & 15 & 16 & 14 \\
Escherichia coli & 12 & 12 & 13 & 15 & 13 \\
Bacilluscereus & 10 & 15 & 16 & 16 & 15.25 \\
Candida albicans & 12 & 13 & 12 & 13 & 11.75 \\
Mean Commiphora myrrh & 12 & 13 & 14 & 15 & 13.5 \\
ethyl acetate resin extract & & & & & \\
\hline
\end{tabular}

Table 9. Inhibition zone (in $\mathrm{mm}$ ) for different concentrations of Commiphora myrrh petroleum ether resin extract

\begin{tabular}{llllll}
\hline Microorganism & \multicolumn{3}{l}{$\begin{array}{l}\text { Concentration of the of } \\
\text { Commiphora myrrh petroleum } \\
\text { ether resin extract }(\mu \mathrm{g} / \mathrm{disc})\end{array}$} & $\begin{array}{l}\text { Mean } \\
\text { Microorganism }\end{array}$ \\
\hline & 12.5 & 25 & 50 & 100 & \\
Salmonella typhimurium & 10 & 10 & 11 & 12 & 10.75 \\
Pseudomonas aeruginosa & 11 & 11 & 12 & 13 & 11.75 \\
Escherichia coli & 12 & 12 & 13 & 14 & 12.75 \\
$\begin{array}{l}\text { Bacilluscereus } \\
\text { Candida albicans }\end{array}$ & 10 & 11 & 11 & 13 & 11.25 \\
Mean Commiphora myrrh & 11 & 12 & 13 & 15 & 12.75 \\
resin extract & 10.8 & 11.2 & 12 & 13.4 & \\
\hline
\end{tabular}

Table 10. Inhibition zone (in $\mathrm{mm}$ ) for different concentrations of Commiphora myrrh chloroform extract

\begin{tabular}{llllll}
\hline Microorganism & \multicolumn{4}{c}{$\begin{array}{c}\text { Concentration of the of } \\
\text { Commiphora myrrh chloroform } \\
\text { resin extract }(\mu \mathrm{g} / \mathrm{disc})\end{array}$} & $\begin{array}{l}\text { Mean } \\
\text { Microorganism }\end{array}$ \\
\hline Salmonella typhimurium & 12.5 & 25 & 50 & 100 & \\
Pseudomonas aeruginosa & 10 & 10 & 10 & 11 & 10 \\
Escherichia coli & 11 & 12 & 11 & 12 & 10.75 \\
$\begin{array}{l}\text { Bacilluscereus } \\
\text { Candida albicans }\end{array}$ & 10 & 10 & 11 & 12 & 10.75 \\
Mean Commiphora myrrh & 12 & 13 & 14 & 15 & 13.5 \\
chloroform resin extract & 10.4 & 11 & 11.8 & 12.8 & \\
\hline
\end{tabular}

zone against Escherichia coli (15.25), while the lower one against Bacillus cereus (11.75).Table 9 show that the Commiphora myrrh resin extracted by petroleum ether, the high inhibited zone against Escherichia coli (12.75) and the lower inhibition zone against Salmonella typhimurium (10.75). Table 10 show the inhibition zone (in $\mathrm{mm}$ ) for different concentrations of Commiphora myrrh chloroform extract the high inhibited zone against Escherichia coli (12.50) and the lower inhibition zone against Salmonella typhimurium $(31,32,33,34)$. All different Commiphora myrrh resin extract (ethanol, ethyl acetate petroleum ether and chloroform) have the high activity against Candida albicans fungus these results agree with those who obtained that their in 


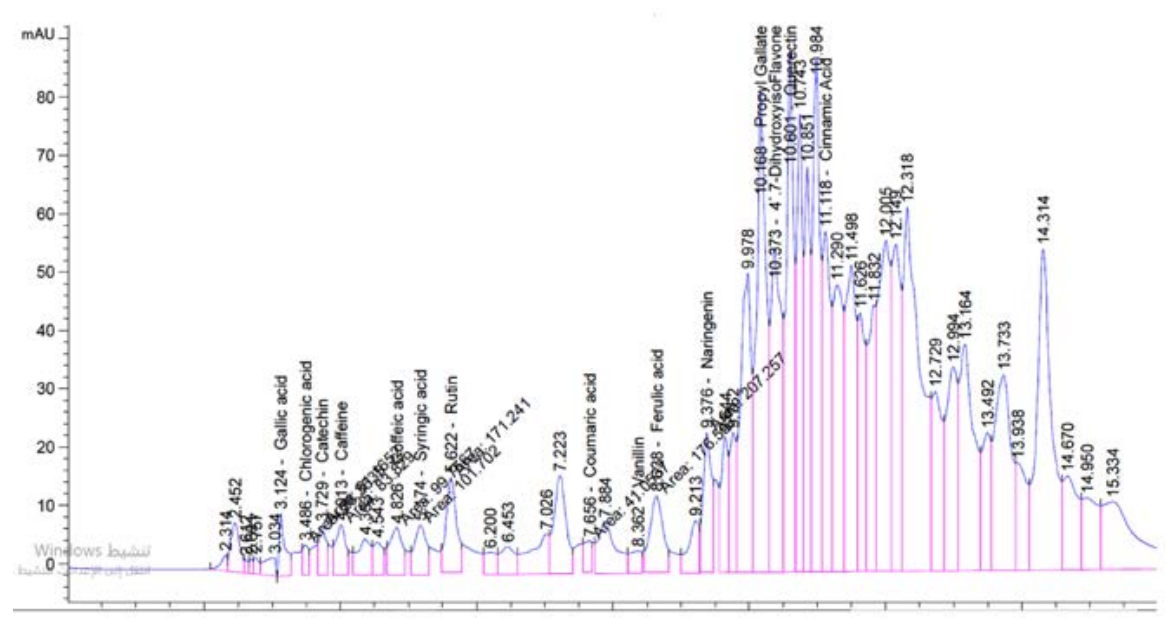

Fig. 1. Commiphora myrrh resin ethanol extract $80 \%(20 \mathrm{mg} / \mathrm{ml})$

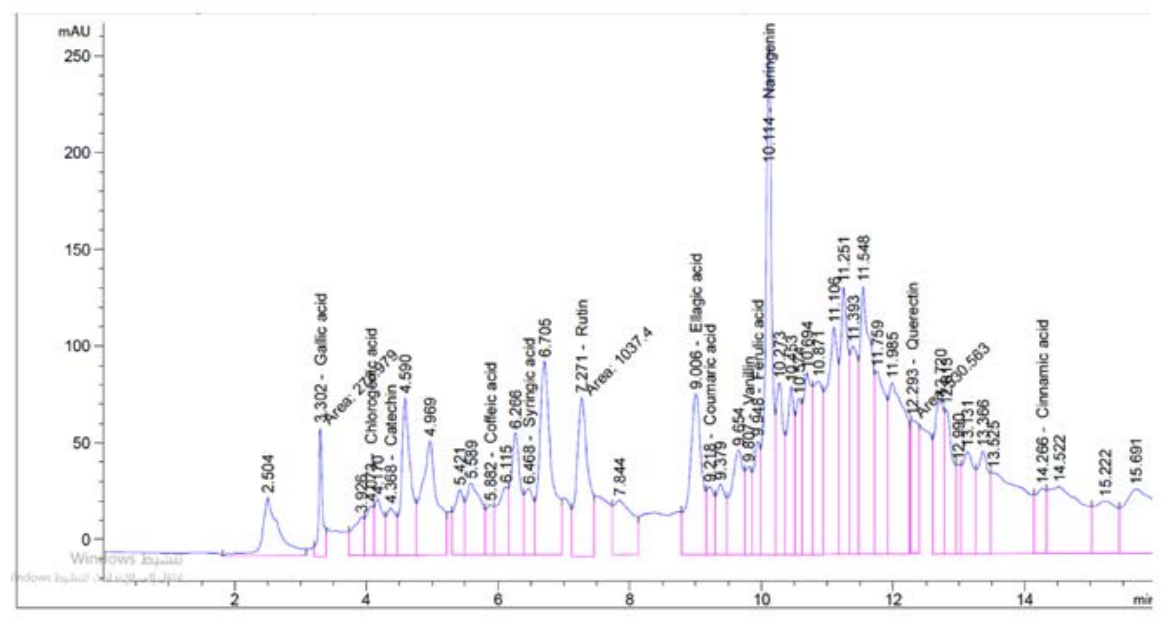

Fig. 2. Commiphora myrrh resin ethyl acetate extract (Conc. $15 \mathrm{mg} / \mathrm{ml}$ )

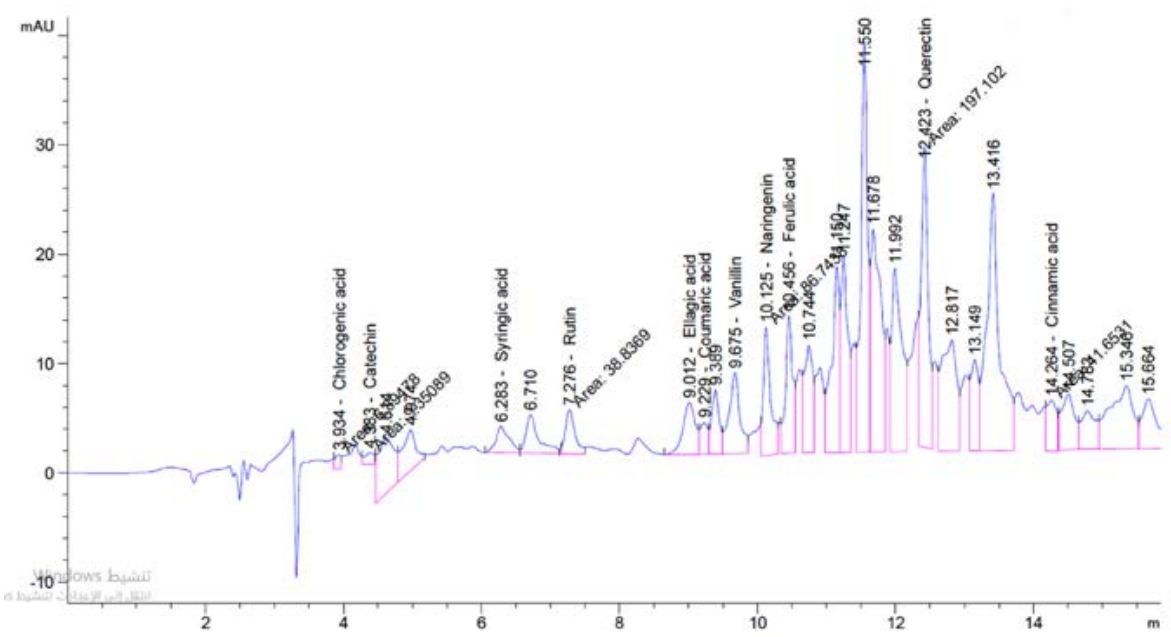

Fig. 3. Commiphora myrrh resin petroleum ether extract (Conc. $15 \mathrm{mg} / \mathrm{ml}$ ) 


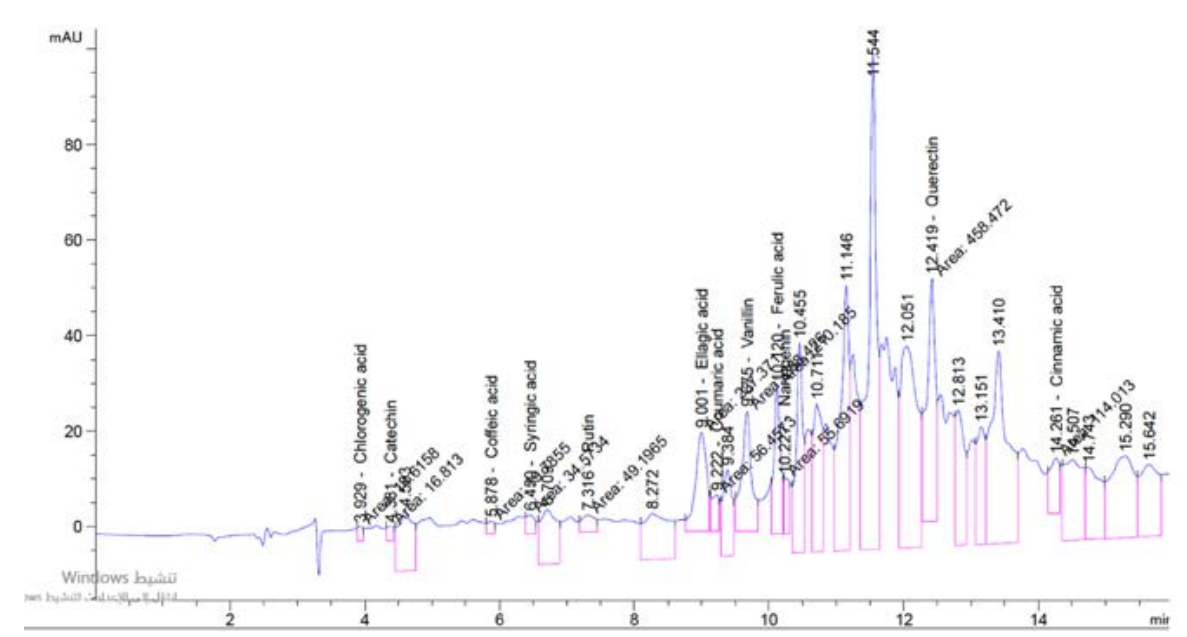

Fig. 4. Commiphora myrrh resin chloroform extract (Conc. $15 \mathrm{mg} / \mathrm{ml}$ )

extract of Commiphora myrrh seed extract have potent effect against bacteria and fungi ${ }^{35}$.

\section{CONCLUSION}

The Commiphora myrrh contain polyphenol compound had potent antioxidant, antibacterial and antifungal activity in all different leaf extract.

\section{ACKNOWLEDGMENTS}

We would like to thanks the all staff of department of Biology, Science and Humanity College in Al-kharj, Prince Sattam bin AbdulAziz University Al-Khaarj Saudi Arabia and department of Chemistry, Faculty of Science and Arts in Mukhwa, University of Albaha, Saudi Arabia for providing assistance on bioinformatics analysis. We would like to thank all the staff of the laboratories of Chemistry and Microbiology "National Research Centre, Khartoum Sudan.

\section{CONFLICT OF INTEREST}

The authors declare that there is no conflict of interest.

\section{AUTHORS' CONTRIBUTION}

All authors listed have made a substantial, direct and intellectual contribution to the work, and approved it for publication.

\section{FUNDING}

None.

\section{ETHICS STATEMENT}

This article does not contain any studies with human participants or animals performed by any of the authors.

\section{DATA AVAILABILITY}

All datasets generated or analyzed during this study are included in the manuscript.

\section{REFERENCES}

1. Kebu B, Ensermu K, Zemede A. Indigenous medicinal utilization, managemetn and threats in Fentale area, Eastern Shewa, Ethiopia. Ethi J Biol Sci. 2004;3:1-7.

2. Evans WC, Evans T. Pharmacognosy. $14^{\text {th }}$ Ed, London: WB Saunders, 1996. 14. Langenheim JH. Plants resins: Chemistry, Evolution, Ecology, and Ethnobotany. Timber Press, Portland, Oregon, USA. 2003.

3. Nikam P, Kareparamban J, Jadhav A, Kadam V: Future Trends in Standardization of Herbal Drugs. J of Applied Pharmaceutical Science. 2012:38-44

4. Chevallier A. Ed.: "The Encyclopedia of Medicinal Plants", 4th ed., 84 (1996) 2 Wallis, T. E. Ed.: "Text book of Pharmacognosy", $5^{\text {th }}$ ed., 497 (1967)

5. Trease GE, Evans WC, Edeoga HO, Okwu DE, Mbaebie BO. Phytochemical constituents of some Nigerian medicinal plants. Afr J Biotechnol. 2005;4:685. doi: 10.5897/AJB2005.000-3127

6. Sofowora A, Ogunbodede E, Onayade A. The role and place of medicinal plants in the strategies for disease prevention. Afr J Tradit Complement Altern Med. 2013;10:210-229. doi: 10.4314/ajtcam.v10i5.2

7. Shen T, Li GH, Wang XN, Lou HX. The genus Commiphora: A review of its traditional uses, phytochemistry and pharmacology. J Ethnopharmacol. 2012;142:319-330. doi: 10.1016/j.jep.2012.05.025

8. Mekonen Y, Dekebo A, Dagne E. Toxcity study in mice of resins of three Commiphora species. SINET: Ethiop. J. Sci. 2003;26:151-153. 
9. Rao RM, Khan ZA, Shah AH. Toxicity studies in mice of Commiphora molmol oleo-gum-resin. J Ethnopharmacol. 2001;76(2):151-154. Frankincense, Myrrh. Economic Botany. 40:425-433. doi: 10.1016/ S0378-8741(01)00189-1

10. Greene DA Gold. frankincense, myrrh and, medicine. NC Med. J. 1993;54:620-622.

11. Dolara P, Luceri C, Ghelardini C, et al. Analgesic effects of myrrh. Nature. 1996;379:29. doi: 10.1038/379029a0

12. Shulan S, Tuanjie W, Jino D, et al. Anti-inflammatory and analgesic activity of different extracts of Commiphora myrrha. J Ethnopharmacol. 2011;134(2):251-258. 10.1016/j.jep.2010.12.003

13. Shalaby MA, Hammouda A-E. Analgesic, anti-infl ammatory and anti-hyperlipidemic activities of Commiphora molmol extract(Myrrh). J Intercult Ethnopharmacol. 2014;3(2):56-62. doi: 10.5455/ jice.20140130015014

14. Mohammed AA, Ali SI, EL-Baz FK, Hegazy AK, Kord MA. Chemical composition if essential oil and in vitro antioxidant and antimicrobial activities of crude extracts of Commiphora myrrha resin. Industrial Crops and Products. 2014;57:10-16.

15. Omar SA, Adam SEI, Mohammed OB. Antimicrobial activity of commiphora myrrha against some bacteria and Candida albicans Isolated from Gazelles at King Khalid Wildlife Research Centre. Research Journal of Medicinal Plants. 2011;5(1):65-71. 10.3923/ rjmp.2011.65.71

16. Duwiejua M, Zeitlin IJ, Waterman PG, Chapman J, Mhango GJ, Provan GJ. Anti-inflammatory activity of resins from some species of the plant family Burseraceae. Planta Med. 1993;59(1):12-16. 10.1055/ s-2006-959594

17. Tariq M, Ageel AM, Al-Yahya MA, Mossa JS, Al-Said MS, Parmar NS. Anti-inflammatory activity of Commiphora molmol. Agents Actions. 1986;17(3-4):381-219. doi: 10.1007/bf01982655

18. Haffor A-SS. Effect of myrrh (Commiphora molmol) on leukocyte levels before and during healing from gastric ulcer or skin injury. J Immunotoxicol. 2010;7:68-75. doi: 10.3109/15476910903409835

19. al-Harbi MM, Qureshi S, Raza M, Ahmed MM, Afzal M, Shah AH. Gastric antiulcer and cytoprotective effect of Commiphora molmol in rats. J Ethnopharmacol. 1997;55(2):141-50.

20. Cheesebrough M. District laboratory practice in tropical countries Part 2. Cambridge University Press; Cambridge: 2000: 63-70.

21. Sadzawka A, Carrasco MA, Demanet R, et al. Method of analysis for vegetables. $2^{\text {nd }}$ Ed.Santiago, Chile. Instituto de Investigaciones Agropecuarias INIA, 2007:140.

22. AOAC. Official methods of analysis of the association of analytical Chemists, Washington D.C. 1990:12-13.
23. Nobosse P, Fombang EN, Mbofung CMF. The effect of steam blanching and drying method on nutrients, phytochemicals and antioxidant activity of Moringa (Moringa oleifera L.) leaves. American Journal of Food Science and Technology. 2017:5(2):53-60. doi: 10.12691/ajfst-5-2-4

24. Omenka CA, Osuoha JO. Antimicrobial potency of grapefruit seed extract on five selected pathogens. Nig J Microbiol. 2000:14(2):39-40.

25. Albuquerque TR, Camara RDR, Marian L, Willadino Marcelin C. Antimicrobial action of the essential oil of Lippia gracilis Schauer. Braz Arch Bio Tech. 2006:49(4):527-535. doi: 10.1590/S151689132006000500001

26. Othman R, Hameed A-SRR, Naji NA. Studying of Phytochemical, Nutritive values and Antioxidant ability of Commiphora myrrha. Al-Mustansiriyh Journal of Pharmaceutical Scienses. 2016:17(1):21-33.

27. Gomez KA, Gomez AA. Statistical procedures for Agriculture Research. seconded . John Wiley and Sons, Inc. New York, 1983.

28. Duyff RL. American Dietetic Association Complete Food and Nutrition Guide. $4^{\text {th }}$ ed. Hoboken, N.J.: John Wiley \& Sons. 2012:55

29. Su S, Wang T, Duan J, et al. "Anti-inflammatory and analgesic activity of different extracts of Commiphoramyrrha," J Ethnopharmacol. 2011;134(2):251-258. dol: 10.1016/j.jep.2010.12.003

30. Su $S$, Hua $Y$, Wang $Y$, et al. "Evaluation of the anti-inflammatory and analgesic properties of individual and combined extracts from Commiphora myrrha, and Boswellia carterii," J Ethnopharmacol. 2012;139(2):649-656. doi: 10.1016/j.jep.2011.12.013

31. Kumar VP, Chauhan NS, Padh H, Rajani M. Search for antibacterial and antifungal agents from selected Indian medicinal plants. J Ethnopharmacol. 2006;107:182. doi: 10.1016/j.jep.2006.03.013

32. Joshi B, Lekhak S, Sharma A. Antibacterial property of different medicinal plants: Ocimum sanctum, Cinnamomum zeylanicum, Xanthoxylum armatum and Origanum majorana. Kathmandu Univ $J$ Sci Eng Technol. 2009;5(1):143-50. doi: 10.3126/kuset. v5i1.2854

33. Das K, Tiwari RK, Shrivastava DK. Techniques for evaluation of medicinal plant products as antimicrobial agent: Current methods and future trends. J Med Plants. 2010;4(2):104-111. doi: 10.5897/JMPR09.030

34. Savluchinske-Feio S, Curto MJM, Gigante B, Roseiro JC. Antimicrobial activity of resin acid derivatives. Appl Microbiol Biotechnol. 2006;72(3):430-436. Res. 2010;4:104-111. doi: 10.1007/s00253-006-0517-0

35. Kalemba D, Kunicka A. Antibacterial and antifungal properties of essential oils. Curr Med Chem. 2003;10(10):813-829. doi: 10.2174/0929867033457719 